\title{
Genetic Diversity Analysis of Soybean [Glycine max (L.) Merrill.] Germplasms in Bangladesh Using SSR Markers
}

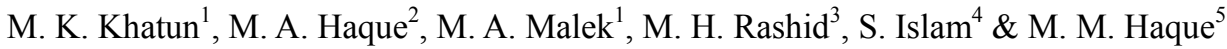 \\ ${ }^{1}$ Plant Breeding Division, Bangladesh Institute of Nuclear Agriculture, Mymensingh, Bangladesh \\ ${ }^{2}$ Department of Genetics and Plant Breeding, Bangladesh Agricultural University, Mymensingh, Bangladesh \\ ${ }^{3}$ Biotechnology Division, Bangladesh Institute of Nuclear Agriculture, Mymensingh, Bangladesh \\ ${ }^{4}$ Seed Processing Centre, Bangladesh Agricultural Development Corporation, Mymensingh, Bangladesh \\ ${ }^{5}$ Plant Pathology Division, Bangladesh Institute of Nuclear Agriculture, Mymensingh, Bangladesh \\ Correspondence: M. K. Khatun, Plant Breeding Division, Bangladesh Institute of Nuclear Agriculture, \\ Mymensingh, Bangladesh. Tel: 88-017-1797-5926. E-mail: khadija_bina@yahoo.com
}

Received: October 31, 2020

Accepted: December 8, 2020

Online Published: January 15, 2021

doi:10.5539/jas.v13n2p1

URL: https://doi.org/10.5539/jas.v13n2p1

\begin{abstract}
The purpose of the present study was to investigate the genetic diversity and molecular characterization of 50 soybean genotypes in Bangladesh with 20 SSR markers. Genomic DNA was isolated by modified standard cetyl tri-methyl ammonium bromide (CTAB) extraction protocol and alleles were amplified by polymerase chain reaction (PCR). Allele sizes were estimated in comparison with 50 bp DNA ladder. The software NTSYSpc version 2.2 and POPGENE version 1.31 were utilized for molecular data analysis and preparation of dendrogram. Polymorphic Information Content (PIC) values varied from 0.53 (Satt664) to 0.98 (Satt009, Satt330 and Satt522) with the mean value 0.897 and expected heterozygosity varied from 0.4059 (Satt685) to 0.1246 (Satt664) with the mean value 0.244 . The dendrogram analysis depicted that the 50 genotypes were grouped in four (4) major clusters. The most diverse genotypes were SBG-1, PM-78-6-3-13, BS-3 and AGS-31, which suggest that the simple sequence repeat (SSR) markers are very efficient for genetic diversity analysis. The similarity matrix revealed the diversity among genotypes. The diverse genetic materials obtained from the present study on genetic diversity of soybean genotypes in Bangladesh may be utilized in the future breeding programme.
\end{abstract}

Keywords: genetic diversity, soybean, SSR primers, varietal identification

\section{Introduction}

Soybean (Glycine $\max (\mathrm{L}$.$) Merr.) is the most vital economic legume crops in the world. It supplies vegetable oil$ which is a crucial source of protein for human and animal nutrition. It is also an important source of bio-diesel (Pimentel \& Patzek, 2008).

Genetic diversity is the evaluation of genetic variability within species which is important for the survival and adaptiveness of the species. The genetic diversity analysis is important to broaden the genetic base of soybean germplasm which can be further used in breeding programs.

DNA markers based molecular characterization of soybean germplasms was more informative, stable, and reliable, as compared to traditional methods like agronomic traits, pedigree analysis and morphological diversity analysis. Molecular markers were used for the identification of genetically diverse genotypes which were further used in a breeding program (Maughan et al., 1996; Thompson \& Nelson, 1998). Molecular markers were used to evaluate genetic variation within the collected germplasms of soybean genotypes which was reported by Mohammadi and Prasanna (2003).

There are various molecular markers, like restriction fragment length polymorphisms (RFLPs), random amplified polymorphic DNAs (RAPDs), amplified fragment length polymorphisms (AFLPs), single nucleotide polymorphisms (SNPs), and microsatellites or simple sequence repeats (SSRs) are often used in the evaluation of soybean. Molecular profiling is preferable in breeding programs because it is reliable, authentic and less influenced by environmental fluctuations (Vinu et al., 2013). Molecular markers can separate the specific genotypes by identifying the presence of unique bands. 
For genetic diversity analysis and molecular characterization in soybean, SSR markers become very important because of their abundance, codominance, high reproducibility (Kujane et al., 2019; Koutu et al., 2019), high polymorphism compared to RFLPs, AFLPs, and RAPDs (Kumawat et al., 2015; Chakraborty et al., 2018; Moniruzzaman et al., 2019) and have a much greater ability to identify unique alleles in parental and elite soybean germplasm than any other markers (Tantasawat et al., 2011).

Russel et al. (2004) found that SSR markers are useful for the determination of genetic relationship and dissimilarity within a population. Microsatellites or SSR markers have high resolving power for evaluation of population (Li et al., 2010). Simko et al. (2012) reported that SSR markers have a high success rate in diversity analysis. Microsatellites or SSR markers are efficiently used for genetic and genomic analysis, genotypic characterization, varietal protection, seed purity estimation, germplasm conservation, diversity analysis, paternity and pedigree analysis, quantitative trait locus (QTL) mapping and marker-assisted breeding (Munir et al., 2013). Wang et al. (2010) and Guan et al. (2010) stated that SSRs marker can be efficiently wont for evaluation of genetic diversity and the relationship among soybean genotypes.

Although there are some studies on soybean diversity analysis but there are very few studies administered in Bangladesh to assess the molecular markers based genetic diversity analysis of soybean. So, the present study was conducted for the identification and genetic diversity analysis of fifty (50) soybean genotypes using 20 SSR markers.

\section{Material and Methods}

The study was carried out at Bangladesh Institute of Nuclear Agriculture (BINA), Mymensingh, Bangladesh during the period of December 2015 to June 2016, located at $24^{\circ} 43^{\prime} 23^{\prime \prime} \mathrm{N}-90^{\circ} 25^{\prime} 53^{\prime \prime} \mathrm{E}$ with an altitude of $518 \mathrm{~m}$ above sea level. Fifty (50) soybean genotypes having high yield potential were used as experimental materials for this study. All these genotypes with their sources of collection are given in Table 1.

Table 1. Experimental materials with their sources of collection

\begin{tabular}{|c|c|c|c|c|c|}
\hline S1 No. & Genotypes & Sources of collection & S1 No. & Genotypes & Sources of collection \\
\hline 1 & G-2120 & BAU, Mymensingh & 26 & BS-3 & BAU, Mymensingh \\
\hline 2 & Gc-84040-27-1 & BAU, Mymensingh & 27 & KADSING & BAU, Mymensingh \\
\hline 3 & MTD-16 & BAU, Mymensingh & 28 & AGS-302 & BAU, Mymensingh \\
\hline 4 & AGS-79 & BAU, Mymensingh & 29 & GAURAB & BAU, Mymensingh \\
\hline 5 & ASSET-93-19-1 & BAU, Mymensingh & 30 & MTD-176 & BAU, Mymensingh \\
\hline 6 & PM-78-6-3-13 & BAU, Mymensingh & 31 & JOYAWIYAJA & BAU, Mymensingh \\
\hline 7 & G-2261 & BAU, Mymensingh & 32 & AGS-314 & BAU, Mymensingh \\
\hline 8 & $\mathrm{~Pb}-1 / \mathrm{SOHAG}$ & BAU, Mymensingh & 33 & BS-13 & BAU, Mymensingh \\
\hline 9 & HIHS-WIHS & BAU, Mymensingh & 34 & LG-92P-1139 & BAU, Mymensingh \\
\hline 10 & MTD-451 & BAU, Mymensingh & 35 & $\mathrm{CH}-1$ & BAU, Mymensingh \\
\hline 11 & BRAGG & BAU, Mymensingh & 36 & ASSET-93-19-2 & BAU, Mymensingh \\
\hline 12 & GC-83005-9 & BAU, Mymensingh & 37 & TAINANS & BAU, Mymensingh \\
\hline 13 & SBG-1 & BAU, Mymensingh & 38 & Lokon & BAU, Mymensingh \\
\hline 14 & SY-35 & BAU, Mymensingh & 39 & $16-81021-16-1$ & BAU, Mymensingh \\
\hline 15 & NO-205 & BAU, Mymensingh & 40 & SBM-15 & BINA, Mymensingh \\
\hline 16 & MTD-6 & BAU, Mymensingh & 41 & SBM-18 & BINA, Mymensingh \\
\hline 17 & AGS-66 & BAU, Mymensingh & 42 & SBM-22 & BINA, Mymensingh \\
\hline 18 & ACC-1222 & BAU, Mymensingh & 43 & SBM-09 & BINA, Mymensingh \\
\hline 19 & BARI-6 & BARI, Gazipur & 44 & SANTAR-05A & BAU, Mymensingh \\
\hline 20 & BINA-2 & BINA, Mymensingh & 45 & AGS-278 & BAU, Mymensingh \\
\hline 21 & BINA-3 & BINA, Mymensingh & 46 & ASSET-93-19-5 & BAU, Mymensingh \\
\hline 22 & BINA-1 & BINA, Mymensingh & 47 & G-10180 & BAU, Mymensingh \\
\hline 23 & BINA-4 & BINA, Mymensingh & 48 & PK-416 & BAU, Mymensingh \\
\hline 24 & BARI-5 & BARI, Gazipur & 49 & DAVIS & BAU, Mymensingh \\
\hline 25 & MINA HAI & BAU, Mymensingh & 50 & YESOY-4 & BAU, Mymensingh \\
\hline
\end{tabular}




\subsection{Plant Growth}

The plants are grown at the glasshouse of Bangladesh institute of nuclear agriculture (BINA), Mymensingh, Bangladesh during the period of December 2015 to March 2016. The plastic pot was prepared with the mixture of $12 \mathrm{~kg}$ air-dried sandy loam soil and cowdung at a ratio of 4:1 holding 28\% moisture at field capacity (FC). Fertilizer was applied in the soil of the pot uniformly with $0.15,0.18,0.36$ and $0.1 \mathrm{~g}$ urea, triple superphosphate, muriate of potash, and gypsum corresponding to 24-30-60-15 kg NPKS per hectare, respectively. Six healthy seeds were sown in a pot. The seedlings were emerged within 6-7 days after sowing. After two weeks of Seedling emergence, only three healthy seedlings of uniform size were keep in a pot and the rest were thinned out.

\subsection{DNA Isolation}

The molecular work was carried out at the molecular laboratory in Plant Breeding Division and Biotechnology Divisions of Bangladesh Institute of Nuclear Agriculture (BINA), Mymensingh, Bangladesh during the period of February 2016 to June 2016.

The fresh young leaves were collected from 21 days old soybean plants for DNA extraction. The total genomic DNA were extracted following the modified standard CTAB DNA extraction protocol (J. J. Doyle \& J. L. Doyle 1990). The quality of DNA was estimated with $1 \%$ agarose gel and quantification of DNA concentration was done by a Thermo Scientific, NanoDrop 2000c spectrophotometer. Dilution of DNA samples were made by using Tris-EDTA (TE) buffer to get a final concentration $100 \mathrm{ng} / \mu \mathrm{l}$. Then, the polymerase chain reaction (PCR) amplification of SSRs marker was done by using the diluted DNA sample. The SSR markers developed by Cregan et al. (1999) were used in the present study. Twenty (20) SSR markers were chosen from 18 chromosomes/linkage groups (out of 20 chromosomes) of soybean for genetic diversity analysis of 50 accessions of soybean germplasm. The supplementary Table 2 represents the name, position, and sequences of the SSR markers.

Table 2. Sequence of SSR Marker for DNA fingerprinting

\begin{tabular}{|c|c|c|c|c|c|}
\hline Sl. No. & SSR locus & $\begin{array}{l}\text { Chromosome } \\
\text { number }\end{array}$ & $\begin{array}{l}\text { Linkage } \\
\text { Group (LG) }\end{array}$ & Forward primer sequence $\left(5^{\prime} \rightarrow 3^{\prime}\right)$ & Reverse primer sequence $\left(5^{\prime} \rightarrow 3^{\prime}\right)$ \\
\hline 1. & Satt165 & 5 & A1 & CACGAATAACTTGACACATT & TAAAAACAAAGCAAACATAAA \\
\hline 2. & Sat_406 & 8 & A2 & GCGCGTGTGGTGGTTACATTA & GCGTTTGCAGCCATTTCCATTTAC \\
\hline 3. & BE806308 & 11 & B1 & GCGATTTGACCCCGTTCATACAT & GCGGCAGAAATCCGCTCTCTTTA \\
\hline 4. & Satt509 & 11 & B1 & GCGCTACCGTGTGGTGGTGTGCTACCT & GCGCAAGTGGCCAGCTCATCTATT \\
\hline 5. & Satt194 & 4 & $\mathrm{C} 1$ & GGGCCCAACTGATATTTAATTGTAA & GCGCTTTGTGTTCCGATTTTGAT \\
\hline 6. & Satt184 & 1 & D1a & GCGCTATGTAGATTATCCAAATTACGC & GCCACTTACTGTTACTCAT \\
\hline 7. & Satt163 & 18 & G & AATAGCACGAGAAAAGGAGAGA & GTGTATGTGAAGGGGAAAAACTA \\
\hline 8. & Sat_210 & 18 & G & GCGCCAGCAACAAAGTTCCTGACAAA & GCGCATGCAAATGAAATAATAA \\
\hline 9. & Sat_339 & 16 & $\mathrm{~J}$ & GCGAAAAAGGATTATGTAAACGGTATAAAAA & GCGGTCGAAAATTTAGGATGTAAGATGTTA \\
\hline 10. & Satt009 & 3 & $\mathrm{~N}$ & CCAACTTGAAATTACTAGAGAAA & CTTACTAGCGTATTAACCCTT \\
\hline 11. & Satt157 & 2 & $\mathrm{Dlb}$ & GGGCTCACTCTCGATAGTAGGTATAAAG & GGGATACCAAAAGGAATAATTGTCTT \\
\hline 12. & Satt434 & 12 & $\mathrm{H}$ & GCGTTCCGATATACTATATAATCCTAAT & GCGGGGTTAGTCTTTTTATTTAACTTAA \\
\hline 13. & Satt545 & 5 & A1 & CAATGCCATTCCATATTTGTT & CAATTGCCCTAGTTTTGATAG \\
\hline 14. & Satt664 & 19 & $\mathrm{~L}$ & GCGTAGATGCTCAACATCAACACTAATCTG & GCGGACGATGAAGAAATATACTATTACGAA \\
\hline 15. & Satt685 & 15 & $\mathrm{E}$ & ATCGTGGCATGTCTCACTAC & GAGGCGGAAGGAAATCTAAT \\
\hline 16. & Satt260 & 9 & $\mathrm{~K}$ & GCGCCAAATGTATACTTTAAATTCTT & GCGGGTTTAGCTAAAATAGTTCGTGC \\
\hline 17. & Satt330 & 20 & I & GCGCCTCCATTCCACAACAAATA & GCGGCATCCGTTTCTAAGATAGTTA \\
\hline 18. & Satt331 & 10 & $\mathrm{O}$ & GCAGAGTCCCCCCTAAATATAG & CGGGAACAACCACACTCTCCATT \\
\hline 19 & Satt460 & 6 & $\mathrm{C} 2$ & GCGCGATGGGCTGTTGGTTTTTAT & GCGCATACGATTTGGCATTTTTCTATTG \\
\hline 20. & Satt522 & 13 & $\mathrm{~F}$ & GCGAAACTGCCTAGGTTAAAA & TTAGGCGAAATCAACAAT \\
\hline
\end{tabular}

Source: Cregan et al. (1999).

\subsection{Simple Sequence Repeats (SSR) Analysis}

The volume of $20 \mu \mathrm{L}$ reaction mixture was used for each PCR reaction. The PCR reaction mixture was prepared with $8 \mu \mathrm{L}$ nuclease-free water, $10 \mu \mathrm{L} 1 \times$ GoTaq green master mix (Promega Corporation, Madison, Wisconsin, USA), 10 pmol of each primer and $100 \mathrm{ng}$ of genomic DNA. The T3 thermocycler (Biometra, Germany) was used to perform the PCR reactions. Thermal profile was slightly modified from Cregan et al. (1999) which was set up with initial denaturation step $95{ }^{\circ} \mathrm{C}$ for 02 min followed by the 35 cycle of denaturation $94{ }^{\circ} \mathrm{C}$ for $60 \mathrm{~s}$, 
annealing $55-58{ }^{\circ} \mathrm{C}$ (as recommended for each SSR primer) for $02 \mathrm{~min}$, extension $72{ }^{\circ} \mathrm{C}$ for $60 \mathrm{~s}$ and final extension $72{ }^{\circ} \mathrm{C}$ for $10 \mathrm{~min}$ ). The $6 \%$ polyacrylamide gels were used for size separation of amplified SSR fragments. The gels were staining with ethidium bromide $(0.5 \mu \mathrm{g} / \mathrm{ml})$ in $1 \mathrm{X}$ TBE buffer and photographs were taken on AlphaImager HP (USA). The fragment sizes were calculated with a compared of 50 bp ladder (Promega Corporation, Madison, Wisconsin, USA).

\subsection{SSR Allele Scoring and Data Analysis}

The PCR products from all the polymorphic SSR markers were analyzed by scoring qualitatively for presence or absence. The SSR markers produced clean bands were scored as 1 (present) and 0 (absent) for each primer. The polymorphism information content (PIC) was calculated by using the following equation according to Botstein et al. (1980):

$$
\mathrm{PIC}=1-\Sigma P_{i}^{2}
$$

Where, $P_{i}$ is the frequency of the $i^{\text {th }}$ allele in the set of genotypes analyzed, calculated for each SSR locus.

The genetic similarity matrix was measured by Jaccard's similarity coefficient. The resulting similarity matrix was further analyzed in the program NTSYSpc version 2.2 (Rohlf, 2000) for the construction of dendrogram by using the unweighted pair-group method arithmetic average (UPGMA) clustering algorithm.

\section{Results and Discussion}

The results of genetic diversity parameters obtained at each locus among 50 soybean genotypes are presented in Table 3. The genetic variability or similarity analysis is very important for the protection of soybean germplasm, their improvement and efficient management. Microsatellite markers based genetic distance information are suitable for the creation of genetic variation by using genetically dissimilar genotypes (Vieira et al., 2007; Vinu et al., 2013). DNA fingerprinting approaches can identify huge amount of loci for extensive variability. The PCR based fingerprinting assay, i.e., SSR or microsatellite markers were used for the evaluation of 50 soybean genotypes. The SSR markers were exhibited a higher number of DNA polymorphism than other molecular markers. In the present study, out of total 20 SSR markers, 18 markers produced polymorphism, which produced $90 \%$ amplification of primer in the 50 soybean genotypes. The amplification of 50 soybean genotypes at primer Satt165 and Satt545 were presented in Figure 1.

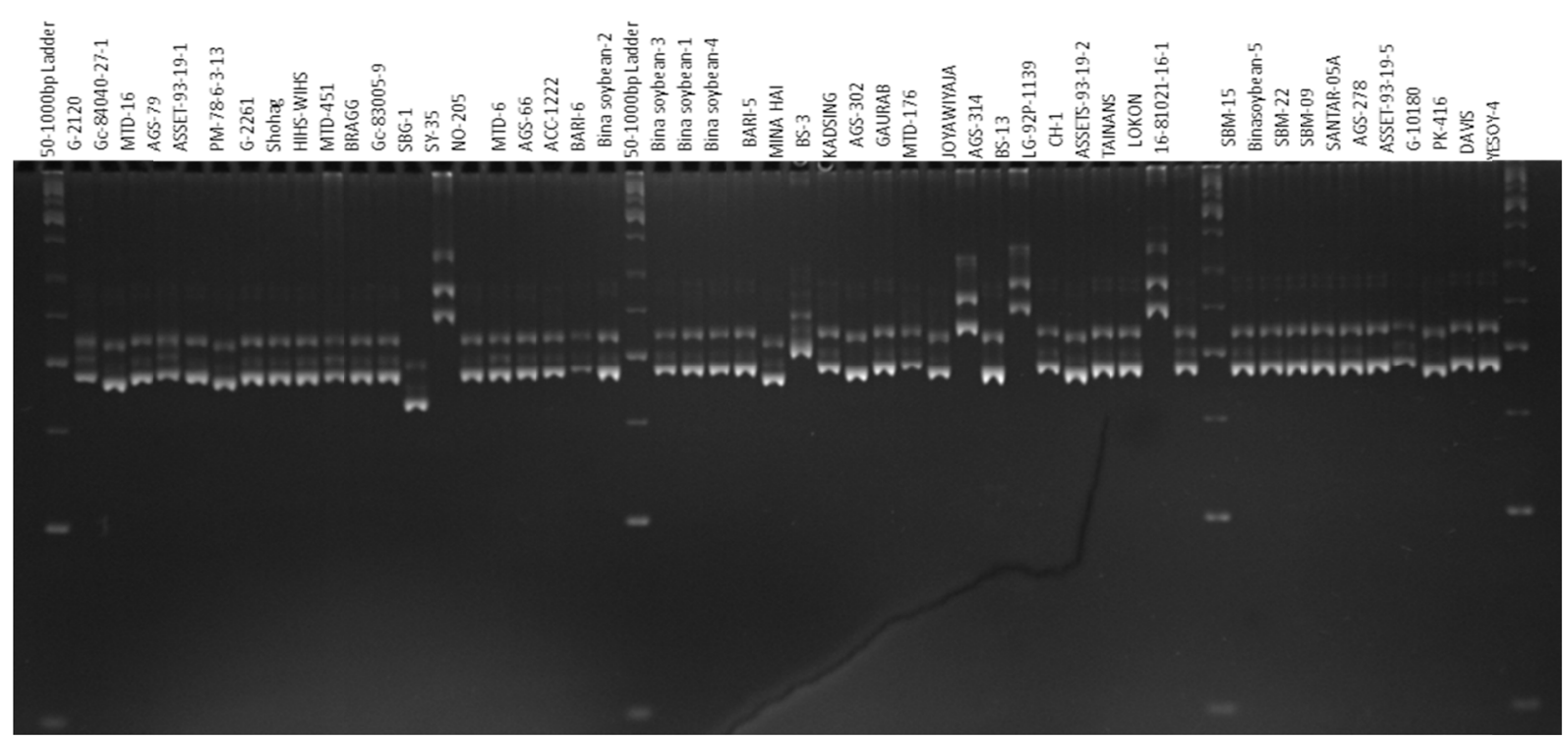

(A) Satt 165 


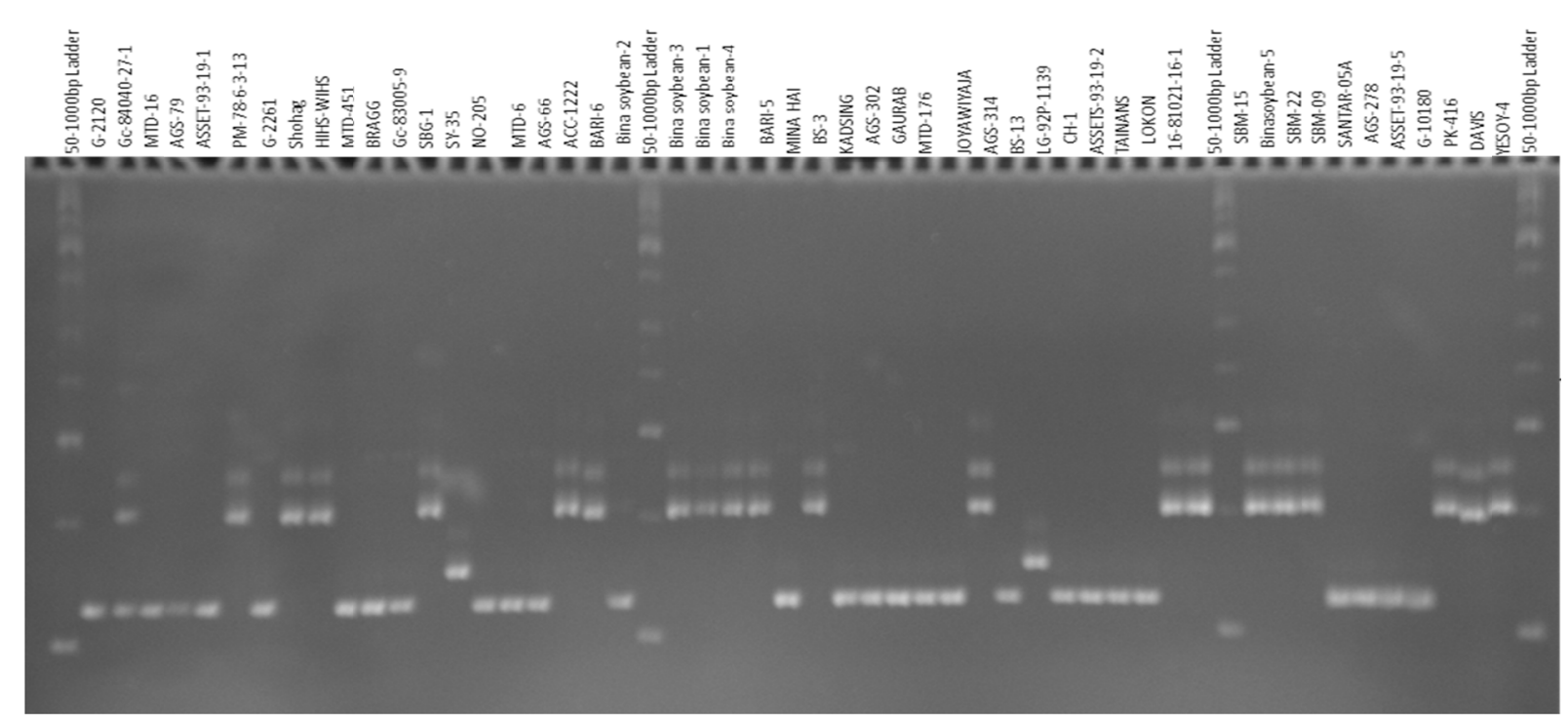

(B) Satt545

Figure 1. The gel electrophoresis DNA bands amplified by (A) Satt165 and (B) Satt545 marker in 50 soybean genotypes

\subsection{Gene Diversity}

The gene diversity of a locus is a basic measurement which estimated the expected proportion of heterozygous genotypes within a population under Hardy-Weinberg equilibrium (Nei, 1972). In the present study, the gene diversity was higher in loci Satt685 (0.406) and lower in loci Satt664 (0.125) with a mean diversity of 0.245 (Table 3). The marker having the highest number of alleles indicated higher gene diversity and marker having the lowest number of alleles indicated lower gene diversity.

Genetic diversity for specific locus was assessed by polymorphic information content (PIC). Allelic diversity and gene frequency among the genotypes were estimated with PIC value. The PIC values are greater than 0.5 for all markers used in the present study. The PIC values varied from 0.53 (Satt664) to 0.98 (Satt009, Satt330, and Satt522) with an average of 0.897 (Table 3) which indicates the informativeness of SSR markers. High PIC values are suggested for the identification of diverse soybean genotypes. The PIC values varied from 0.55 to 0.66 with an average of 0.36 for the marker Sat554, Sat180, Sat600 and Sat478 having 4 alleles per locus were reported by Hipparagi et al. (2017). Kumawat et al. (2015) reported that the PIC value was 0.50 for SSRs primer Satt411 and 0.41 for primer BE806308 on genetic diversity analysis of 82 soybean accessions in India. Previous works were reported the PIC values ranged from 0.199 to 0.87 (Wang et al., 2006, Hisano et al., 2007; Zhang et al., 2013; Kim et al., 2014; Bisen et al., 2015).

The expected Heterozygosity was higher in Satt685 (0.4059) and lower in Satt664 (0.1246) with an average of 0.244 (Table 3). The study revealed that the group gene frequency varied from 0.12 (Satt522) to 0.69 (Satt664) and the average of 0.29 . The range of Effective number of alleles were 1.172 (Satt664) to 1.761 (Satt685) with a mean of 1.402. The Shannon's Information index ranges from 0.223 (Satt664) to 0.584 (Satt685). The Shannon's information index of 0.383 (mean) in the present study was lower than the results obtained by Zhao et al. (2018) who reported Shannon's information index of 2.528. The results of Shannon's information index indicating the presence of moderate genetic variation among the genotypes (Table 3). 
Table 3. Group gene frequency, effective number of alleles, genetic diversity/heterozygosity, Shannon's Information index and PIC value

\begin{tabular}{|c|c|c|c|c|c|c|}
\hline Sl. No. & $\begin{array}{l}\text { Name of SSR } \\
\text { marker }\end{array}$ & $\begin{array}{l}\text { Group gene } \\
\text { frequency }\end{array}$ & $\begin{array}{l}\text { Effective number } \\
\text { of alleles (ne*) }\end{array}$ & $\begin{array}{l}\text { Gene diversity/ } \\
\text { heterozygosity }\left(\mathrm{h}^{*}\right)\end{array}$ & $\begin{array}{l}\text { Shannon's } \\
\text { information index }\left(I^{*}\right)\end{array}$ & PIC value \\
\hline 1 & Satt009 & 0.15 & 1.298 & 0.189 & 0.311 & 0.98 \\
\hline 2 & Satt163 & 0.41 & 1.400 & 0.255 & 0.406 & 0.84 \\
\hline 3 & Satt165 & 0.43 & 1.280 & 0.201 & 0.342 & 0.81 \\
\hline 4 & Satt184 & 0.27 & 1.459 & 0.269 & 0.414 & 0.92 \\
\hline 5 & Satt194 & 0.34 & 1.599 & 0.334 & 0.497 & 0.89 \\
\hline 6 & Satt509 & 0.33 & 1.402 & 0.262 & 0.414 & 0.89 \\
\hline 7 & Sat_406 & 0.26 & 1.497 & 0.302 & 0.462 & 0.93 \\
\hline 8 & BE806308 & 0.33 & 1.540 & 0.311 & 0.464 & 0.89 \\
\hline 9 & Satt157 & 0.19 & 1.289 & 0.189 & 0.312 & 0.96 \\
\hline 10 & Satt260 & 0.22 & 1.358 & 0.221 & 0.351 & 0.95 \\
\hline 11 & Satt330 & 0.13 & 1.279 & 0.192 & 0.317 & 0.98 \\
\hline 12 & Satt331 & 0.29 & 1.506 & 0.290 & 0.433 & 0.92 \\
\hline 13 & Satt434 & 0.23 & 1.403 & 0.233 & 0.358 & 0.95 \\
\hline 14 & Satt460 & 0.18 & 1.354 & 0.210 & 0.331 & 0.97 \\
\hline 15 & Satt522 & 0.12 & 1.286 & 0.194 & 0.326 & 0.98 \\
\hline 16 & Satt545 & 0.20 & 1.353 & 0.222 & 0.356 & 0.96 \\
\hline 17 & Satt664 & 0.69 & 1.172 & 0.125 & 0.223 & 0.53 \\
\hline 18 & Satt685 & 0.45 & 1.761 & 0.406 & 0.584 & 0.79 \\
\hline 19 & Sat_210 & Monomorphic & - & - & - & - \\
\hline 20 & Sat_339 & Monomorphic & - & - & - & - \\
\hline Mean & & 0.29 & 1.402 & 0.245 & 0.383 & 0.897 \\
\hline
\end{tabular}

The pair-wise comparisons of Nei's (1972) genetic distance between genotypes were varied from 0.0046 to 0.5470 , which was estimated with combined data of 18 primers.

\subsection{Genetic Similarity Analysis Using UPGMA}

The similarity coefficients matrix was used for UPGMA cluster analysis. The pair-wise genetic similarity for 50 soybean accessions ranged from 0.304 to 0.95 . The dendrogram constructed considering the genetic similarity coefficient of 0.389 among genotypes showed that the 50 genotypes produced four (IV) major clusters (Figure 2) Cluster I is the largest consisting of 40 genotypes. Cluster II having six genotypes namely PK-416, Lokon, YESOY-4, BINA-2, SY-35 and HIHS-WIHS. Cluster III having two genotypes namely BS-3 and AGS-31. Cluster IV having two genotypes namely SBG-1 and PM-78-6-3-13. Cluster I and II were divided into sub-clusters, sub-sub cluster, sub-sub-sub cluster. The nearly closest genotypes in cluster I was BINA-1 and BINA-4 with a similarity coefficient of 0.95 followed by MTD-176 and GAURAB with a similarity coefficient of 0.88 . Bisen et al. (2015) analyzed 38 soybean genotypes using 16 SSR markers were found two major clusters, which were further divided into two sub-clusters. Another study by Hipparagi et al. (2017) reported three distinct clusters in 75 genotypes using 21 SSR markers and two distinct clusters reported by Hirota et al. (2012). From some other study, Tantasawat et al. (2011) found four major clusters in 25 soybean genotypes, whereas Wang et al. (2006) and Ghosh et al. (2014) found two major clusters using SSR markers. The results of the present study are consistent with the findings of Wang et al. (2006), Wen et al. (2008), Hirota et al. (2012), Ghosh et al. (2014) and Bisen et al. (2015). The genotypes used in this study belonged to different clusters because of the genetic variation among them. 


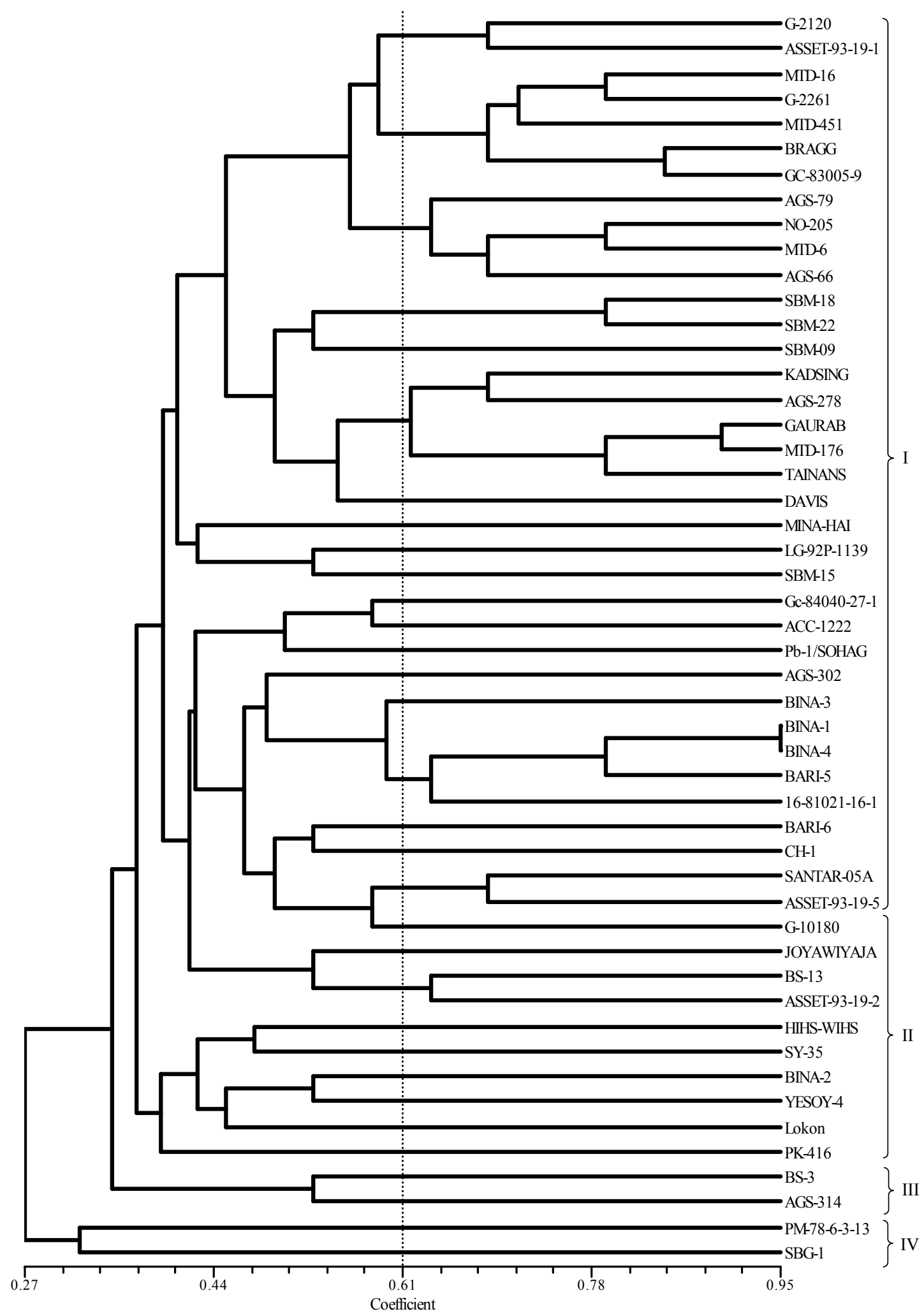

Figure 2. The dendrogram of genetic similarity among 50 soybean genotypes based on UPGMA clustering of Jaccard's similarity coefficients

Among six improve cultivated varieties, five were found in a single cluster I. The clustering of a large number of released varieties together in a single cluster indicating that those were developed from common parents. The results revealed that most released varieties are genetically dissimilar. A large number of soybean germplasm in a 
single cluster I represent that the collected soybean germplasms of Bangladesh are genetically related but the genotypes of cluster II, III and IV possessing a diverse genetic backgrounds. The soybean genotypes used in the present study having the narrow genetic base. So, introduction of different exotic germplasm and utilization of wild species and wild relatives is essential for broadening the genetic diversity in Bangladesh. The genotypes having diverse genetic base may be used as a source of new alleles in soybean breeding program. The clustering analysis in the present study helps the breeder understand the genetic structure of the breeding material for effective and efficient selection. In the future, crossing must be carried out between the clusters and avoiding within the clusters as a way of widening and maintaining genetic dissimilarity among genotypes.

\section{Conclusion}

For the assessment of fifty (50) soybean genotypes with the use of 20 SSR markers found that there was genetic variability among these genotypes. Four major clusters were detected and the cluster I and II had been divided into sub-clusters, sub-sub cluster, sub-sub-sub cluster. The genetic diversity analysis is very important to categorize the genotypes in various clusters for the development of numerous genetic materials. Various heterotic combinations will be produced by the crossing or hybridization among different genetic materials.

\section{References}

Bisen, A., Khare, D., Nair, P., \& Tripathi, N. (2015). SSR analysis of 38 genotypes of soybean (Glycine max (L.) Merr.) genetic diversity in India. Physiol Mol Biol Plants, 21, 109-11. https://doi.org/10.1007/s12298014-0269-8

Botstein, D., White, R. L., Skolnick, M., \& Davis, R. W. (1980). Construction of a genetic linkage map in man using restriction fragment length polymorphism. Am J Hum Genet, $32,3$.

Chakraborty, S., Patel, D. A., Parmar, H., Dhaduk, H. L., \& Sasidharan, N. (2018). Genetic diversity analysis in soybean (Glycine max (L.) Merrill.) using SSR markers. Journal of Pharmacognosy and Phytochemistry, $7(3), 2380-2384$.

Cregan, P. B., Jarvik, T., Bush, A. L., Shoemaker, R. C., Lark, L. G., \& Kahler, A. L. (1999). An integrated linkage map of the soybean genome. Crop Sci, 39, 1464-1490. https://doi.org/10.2135/cropsci1999. $3951464 x$

Doyle, J. J., \& Doyle, J. L. (1990). Isolation of plant DNA from fresh tissue. Focus, 12, 13-15. https://doi.org/ $10.2307 / 2419362$

Ghosh, J., Ghosh, P. D., \& Choudhury, P. R. (2014). An assessment of genetic relatedness between soybean [Glycine max (L.) Merrill] cultivars using SSR markers. Am J Plant Sci, 5, 3089-3096. https://doi.org/ 10.4236/ajps.2014.520325

Guan, R., Chang, R., Li Y., Wang, L., Liu, Z., \& Qiu, L. (2010). Genetic diversity comparison between Chinese and Japanese soybeans (Glycine max (L.) Merr.) revealed by nuclear SSRs. Genet Resour Crop Evol, 57, 229-242. https://doi.org/10.1007/s10722-009-9465-8

Hipparagi, Y., Singh, R., Choudhary, D. R., \& Gupta, V. (2017). Genetic diversity and population structure analysis of Kala bhat (Glycine $\max$ (L.) Merrill) genotypes using SSR markers. Hereditas, 154, 9. https://doi.org/10.1186/s41065-017-0030-8

Hirota, T., Sayama, T., Yamasaki, M., Sasama, H., Sugimoto, T., Ishimoto, M., \& Yoshida, S. (2012). Diversity and population structure of black soybean landraces originating from Tanba and neighboring regions. Breed Sci., 61, 593-601. https://doi.org/10.1270/jsbbs.61.593

Hisano, H., Sato, S., \& Isobe, S. (2007). Characterisation of soybean genome using EST-derived microsatellite markers. DNA Res., 14, 271-281. https://doi.org/10.1093/dnares/dsm025

Kim, K. S., Chirumamilla, A., Hill, C. B., Hartman, G. L., \& Diers, B. W. (2014). Identification and molecular mapping of two soybean aphid resistance genes in soybean PI 587732. Theor Appl Genet, 127, 1251-1259. https://doi.org/10.1007/s00122-014-2296-9

Koutu, G. K., Shrivastava, A., Singh, Y., \& Tiwari, S. (2019). Molecular characterization and genetic diversity assessment of soybean varieties using SSR markers. International Journal of Current Microbiology and Applied Science, 8(04), 173-182. https://doi.org/10.20546/ijcmas.2019.804.018

Kujane, K., Sedibe, M. M., \& Mofokeng, A. (2019). Genetic diversity analysis of soybean (Glycine max (L.) Merrill.) genotypes making use of SSR markers. Australian Journal of Crop Science, 13(07), 1113-1119. https://doi.org/10.21475/ajcs.19.13.07.p1638 
Kumawat, G., Singh, G., Gireesh, C., \& Shivakumar, M. (2015). Molecular characterization and genetic diversity analysis of soybean (Glycine max (L.) Merrill.) germplasm accessions in India. Physiology and Molecular Biology, 21(1), 101-107. https://doi.org/10.1007/s12298-014-0266-y

Li, Y. H., Li, W., Zhang, C., Yang, L., Chang, R. Z., Gaut, B. S., \& Qiu, L. J. (2010). Genetic diversity in domesticated soybean (Glycine max) and its wild progenitor (Glycine soja) for simple sequence repeat and single-nucleotide polymorphism loci. New Phytol, 188, 242-253. https://doi.org/10.1111/j.1469-8137.2010. 03344.x

Maughan, P. J., Saghai, Maroof, M. A., Buss, G. R., \& Huestis, G. M. (1996). Amplified fragment length polymorphism (AFLP) in soybean: species diversity, inheritance and near isogenic line analysis. Theor Appl Genet, 93, 392-401. https://doi.org/10.1007/BF00223181

Mohammadi, S. A., \& Prasanna, B. M. (2003). Analysis of genetic diversity in crop plants salient statistical tools and considerations. Crop Science, 43, 1235-1248. https://doi.org/10.2135/cropsci2003.1235

Moniruzzaman, M., Saiem, R. M., Emon, R. M., Haque, M. S., Saha, N. R., Malek, M. A., \& Khatun, K. (2019). Genetic diversity analysis of soybean genotypes using SSR markers for salinity tolerance. Progressive Agriculture, 3030(1), 1-9. https://doi.org/10.3329/pa.v30i1.42051

Munir, A., Armghan, S., Iqbal, M., Asif, M., \& Hirani, A. H. (2013). Morphological and molecular genetic variation in wheat for salinity tolerance at germination and early seedling stage. Australian Journal of Crop Science, 7(1), 66-74.

Nei, M. (1972). Genetic distance between populations. Am Nat, 106, 283-292. https://doi.org/10.1086/282771

Pimentel, D., \& Patzek, T. W. (2008). Ethanol production using corn, switch grass and wood; biodiesel production using soybean. In D. Pimentel (Ed.), Biofuels, Solar and Wind as Renewable Energy Systems: Benefits and Risks (pp. 375-396). Springer, Dordrecht, The Netherlands.

Rohlf, F. J. (2000). NTSYS-pc: Numerical taxonomy and multivariate analysis system (Version 2.2). Exeter Software, Setauket, New York, USA.

Russel, J., Booth, A., Fuller, J., Harrower, B., Hedley, P., Machray, G., \& Powell, W. (2004). A comparison of sequence-based polymorphism and haplotype content in transcribed and anonymous region of the barley. Genome, 47, 389-398. https://doi.org/10.1139/g03-125

Simko, I., Eujayl, I., \& van Hintum, T. J. (2012). Empirical evaluation of DArT, SNP and SSR marker-systems for genotyping, clustering and assigning sugar beet hybrid varieties into populations. Plant Sci., 184, 54-62. https://doi.org/10.1016/j.plantsci.2011.12.009

Soheil, K., Shamsi, K., \& Rasekhi, B. (2011). Soybean production under water deficit conditions. Annals of Biological Research, 2, 423.

Tantasawat, P., Trongchuen, J., Prajongjai, T., Jenweerawat, S., \& Chaowiset, W. (2011). SSR analysis of soybean (Glycine $\max (\mathrm{L}$.$) Merr.) genetic relationship and variety identification in Thailand. Australian$ Journal of Crop Science, 5(3), 283-290.

Thompson, J. A., \& Nelson, R. L. (1998). Utilization of diverse germplasm for soybean yield improvement. Crop Sci., 38, 1362-1368. https://doi.org/10.2135/cropsci1998.0011183X003800050035x

Vieira, E., Carvalho, F., Bertan, I., Kopp, M., Zimmer, P., Benin, G., ... de Oliviera, A. (2007). Association between genetic distances in wheat (Triticum aestivum L.) as estimated by AFLP and morphological markers. Genet. Mol. Biol., 30, 392-399. https://doi.org/10.1590/S1415-47572007000300016

Vinu, V., Singh, N., Vasudev, S., Yadava, D. K., Kumar, S., Naresh, S., ... Prabhu, K. V. (2013). Assessment of genetic diversity in Brassica juncea (Brassicaceae) genotypes using phenotypic differences and SSR markers. Rev. Biol. Trop., 61(4), 1919-1934.

Wang, L., Guan, R., Zhangxiong, L., Chang, R., \& Qiu, L. (2006). Genetic diversity of Chinese cultivated soybean revealed by SSR markers. Crop Sci., 46, 1032-1038. https://doi.org/10.2135/cropsci2005.0051

Wang, M., Li, R. Z., Yang, W. M., \& Du, W. J. (2010). Assessing the genetic diversity of cultivars and wild soybeans using SSR markers. Afr. J. Biotechnol., 9, 4857-4866.

Wen, Z. X., Zhao, T. J., Zheng, Y. Z., Liu, S. H., Wang, C. E., Wang, F., \& Gai, J. Y. (2008). Association analysis of agronomic and quality traits with SSR markers in Glycine max and Glycine soja in China: I. Population 
structure and associated markers. Acta Agron. Sin., 34, 1169-1178. https://doi.org/10.1016/s1875-2780 (08)90000-6

Zhang, G. W., Xu, S. C., Mao, W. H., Hu, Q. Z., \& Gong, Y. M. (2013). Determination of the genetic diversity of vegetable soybean [Glycine $\max (\mathrm{L}$.$) Merr.] using EST-SSR markers. J. Zhejiang Univ. Sci., 4, 279-288.$ https://doi.org/10.1631/jzus.B1200243

Zhao, H., Wang, Y., Xing, F., Liu, X., Yuan, C., Qi, G., \& Dong, Y. (2018). The genetic diversity and geographic differentiation of the wild soybean [Glycine soja (L.) Merrill.] in Northeast China based on nuclear microsatellite variation. International Journal of Genomics, 508, 1-9. https://doi.org/10.1155/2018/8561458

\section{Copyrights}

Copyright for this article is retained by the author(s), with first publication rights granted to the journal.

This is an open-access article distributed under the terms and conditions of the Creative Commons Attribution license (http://creativecommons.org/licenses/by/4.0/). 